Memories provoke new plans

\section{San Franclsco}

Амвiтious plans to create a unique semiconductor company called US Memories Inc. from a consortium of US computer and chip makers are stirring a debate over efforts to counter Japanese inroads into high technology that could dictate the direction of future antitrust laws.

The new venture, announced last week, would employ capital from existing companies with the aim of re-establishing the United States' role as a leading producer of dynamic random access memory chips (DRAMs). These chips are regarded as drivers of many other technologies because of the critical role they play in a variety of electronic products. But while advocates hail the plan as a way to recover from 'unfair' Japanese trade practices, opponents denounce it as both a violation of antitrust law and just plain stupid.

The controversy is shaping up as a heavyweight fight: IBM, Hewlett-Packard, Intel, Digital Equipment Corporation, National Semiconductor, LSI Logic and Advanced Micro Devices have already contributed $\$ 50,000$ each. They and other backers are talking of putting up at least half the estimated $\$ 1,000$ million necessary to compete with Japanese giants such as Fujitsu, Toshiba and NEC.

Initially, US Memories would manufacture 4-megabit DRAMs based on technology licensed from IBM. To blunt the Japanese edge, backers would promise to buy at least half the consortium's output. DRAMs were pioneered by the US company Intel in the early 1970 s. But whereas 11 US companies produced DRAMs in 1980 , only two do so now.

The new venture is reminiscent of SEMATECH, a Texas-based consortium set up to conduct semiconductor research and development. SEMATECH was itself a reaction to Japanese successes in getting competing companies to conduct joint research and development at the stage before production begins. Under existing US law, such ventures cannot manufacture products - but US Memories president Sanford Kane, who helped form SEMATECH, hopes to find a way around that obstacle.

Some electronics companies are already crying foul. "This is another deal like SEMATECH where we wrap ourselves in the American flag, scream Japanese and go to do something which isn't right to do", proclaims T.J. Rodgers, president and chief executive officer of Cypress Semiconductor Corporation in California.

He predicts that US Memories will expand into other semiconductor arenas - such as the static RAMs that Cypress produces - and has threatened to sue the new venture for violating antitrust laws.

Indeed, removing such a legal threat is critical to US Memories. "In order for them to have security in assessing the future, antitrust rules ought to be relaxed", says Thomas Jorde, a law professor and antitrust specialist at the University of California, Berkeley. His work helped to form the basis for the National Cooperative Innovation and Commercialization Act of 1989, introduced by congressmen Tom Campbell (Republican, California) and Rick Boucher (Democrat, Virginia). The bill would allow the government to protect some joint ventures that violate antitrust regulations.

Private parties can at present collect treble damages by winning an antitrust lawsuit. The new bill, now with a House of Representatives subcommittee, would still permit a successful suit to stop the practice - but no damages would be awarded. Jorde says that situation would be similar to provisions in both Europe and Japan.

Campbell stresses that his bill applies only in special cases. He says: "It only guarantees the ability to do a joint venture if the joint venture will not harm competition but improve competition." But Campbell insists the spectre of treble damages must be erased. "It is the liabilty for damages that chills a lot of American firms' interest in collaborative effort." $\mathrm{He}$ argues that Rodgers' actions prove the point. "His ability to sue under existing law is precisely what I'm attempting to cure. The threat of a lawsuit from Cypress Semiconductor may be enough to keep

Yet another view comes from George Gilder, an author specializing in the economics of technology. He maintains that antitrust is not the issue. "What it is, is stupid", he says. "And that doesn't have anything to do with antitrust." The US companies already producing DRAMs have excellent products, Gilder asserts, and another venture is just not needed. He notes, however, that some initial backers once produced DRAMs and might use the new company to re-enter the market without high start-up costs. Computer makers also might support US Memories because the added competition would lower chip prices. "Those are interesting interests, but they have nothing to do with the future of American technology", says Gilder.

In the meantime, US Memories continues gearing up for operation and expects a government go-ahead on antitrust matters. But Washington's blessing does not remove the threat of a private suit, and many parties involved in the debate are due in Washington later this month to testify on the Campbell bill. Its fate might decide the fate of US Memories. US Memories from happening."
NSF fellows prefer to work at home

\section{Washington}

THE number of US postdoctoral fellows supported by the National Science Foundation (NSF) who plan to spend time working abroad has dropped by half since the early 1970s. Recent NSF data show that only roughly 300 postdocs - or just over 2 per cent of all US science and engineering $\mathrm{PhD}$ recipients - plan to work outside the United States.

The decline in young scientists' interest in doing research overseas was charted last week at a meeting of the National Science Board, NSF's policy-making body. Richard Ries, who oversees NSF

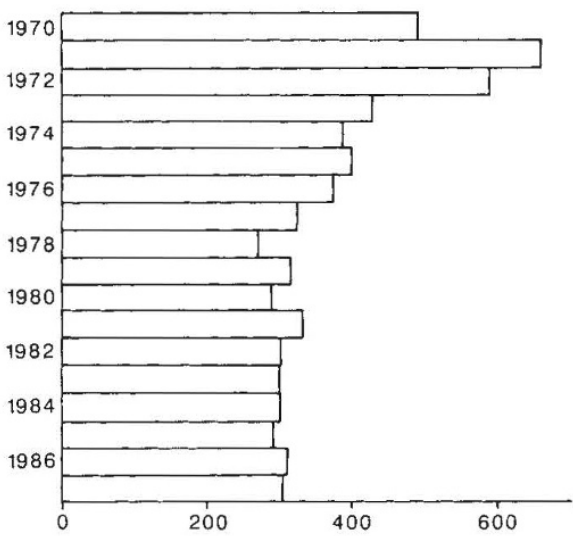

international affairs, said a fall in the number of US researchers with experience abroad could be damaging to international scientific cooperation, just as international projects are becoming more important. Ries cited the pressure to stay in the academic tenure track and the difficulty in finding US research positions from abroad as reasons given by many postdocs for not seeking jobs in other countries.

Carol Ezzell

\section{ANIMAL WELFARE}

\section{Lyons monkeys poorly}

\section{Paris}

THE 28 stolen monkeys belonging to Unit 96 of the institutes of health and medical research (INSERM) at Lyons, discovered in a private house two weeks ago, have now been identified by the researchers. A spokesman for the research group says that, contrary to what they had been led to believe by police (see Nature 339, 648; 29 June 1989), the animals are in a "very poor condition". They are being kept in a zoo and are said to be fighting each other. The tattoo marks that identify each animal have been removed by cutting out the skin; the wounds have not healed and some females may have lost the capacity to suckle. As one team is interested in the developing brain, the animals must be able to reproduce. They will eventually be returned to the laboratory. Peter Coles 